\title{
DEVELOPMENT OF A DANISH MODEL FOR PLANT APPRAISAL
}

\author{
By Thomas B. Randrup
}

\begin{abstract}
Inspired by the American Council of Tree and Landscape Appraisers, the Danish Tree Care Association (ISA's Denmark Chapter) initiated a group of national experts, representing various green-industry associations, in order to develop a common tree valuation model of specific relevance for Danish climate, culture, and traditions. The model (VAT03) has four primary factors: (1) a basis value, (2) health condition of the tree, (3) location of the tree, and (4) tree age. The new model establishes a value that is approximately 10 times higher than was past practice. However, tree values using this model are presumably lower than what can be assessed by other models. The model was introduced in 2003 and has already been used in several, and very different, court cases.
\end{abstract}

Key Words. Urban trees; value; appraisal; Denmark.

\section{BACKGROUND}

Trees are present in parks, on squares, along streets and roads, in yards, and even on rooftops. Whether trees are self-seeded or planted, they provide the environment with technical, architectonic, and ecological goods and services (e.g., Miller 1997; Forrest et al. 1999). Goods and services provided by trees may be difficult to assess in economic terms. However, several studies have either done so or discussed tree values (e.g., Thompson et al. 1999; CTLA 2000; Tyrväinen et al. 2002; Watson 2002; Price 2003).

The immediate need for a reliable valuation model is found in court cases, in which a damaged or felled tree is the subject. In Danish court cases, establishing the value of a tree is a somewhat varied and unstructured practice (Holgersen 1995). This has indicated the need for a recognized valuation model in Denmark. Such a model may also be used in a planning situation and as a economic tool for the protection of trees. Substantial funds are used when urban trees are planted, not only in Denmark but throughout Europe (Pauleit et al. 2002), as well as in the United States (e.g., Harris et al. 2004).

A tree valuation model was previously developed specifically for Danish use (Tolstrup 1972). However, this model has not been broadly adopted. As a consequence, a Danish bachelor's thesis evaluated six different tree appraisal methods from across the world (Poulsen 1999). The models originated from the following countries: Australia (Thyer 1996), Denmark (Tolstrup 1972), Germany (Koch 1987), Norway (Hageselskapet 1998), the United Kingdom (Helliwell 2000), and the United States (CTLA 1992). The different models vary in approach, and in the final value of a tree. Based on the six different models, the thesis presented a new proposal, which was used as a background for more detailed discussions.

Inspired by the American Council of Tree and Landscape Appraisers, the Danish Tree Care Association (ISA's Denmark Chapter) initiated a group of national experts, representing various green-industry associations, in order to develop a common tree valuation model of specific relevance for Danish climate, culture, and traditions. Based on the work by Poulsen (1999), they developed a valuation model that should be simple, and preferably generate a higher tree value, than what was previously seen. While it was an objective to create a model that could establish values higher than observed in current practice, it was not an intent to create a system that would establish values as high as possible. It was a goal to create a model that could be used under almost all circumstances, and thus adopted by the Danish court system.

The Danish Model (VAT03) (Randrup et al. 2003) has been developed to be used under four different circumstances:

1. A tree is damaged to a degree to which the tree will have to be felled. It may be a public or a private tree that has been felled or damaged without permission. The owner (public or private) wishes economic compensation by demanding that the person who caused the damage be legally responsible.

2. An existing tree needs to be protected during a construction period, and a penalty value is calculated in order to prevent builders, entrepreneurs, and others involved in the project from damaging the tree. In this case, the tree health and life expectancy will be assessed prior to the construction period. The Location Factor (see below) will be assessed according to the expected location of the tree after construction.

3. One or several trees need an economic valuation due to expropriation, or under similar circumstances, where the total value of trees in a park, along a street, or within another geographic area is needed for planning reasons.

4. A tree is damaged to an extent where it loses value but does not need to be removed completely. The model may then be used to assess the value of the tree before and after the damage. The difference between the two valuations constitutes the appraised value of the damage. 
In general, the value of a tree derived from this model should be seen as a compensatory value for the damage done.

\section{PRESENTATION OF THE MODEL}

The Danish model takes its point of departure in the replacement cost of a new tree of a reasonable size that can be purchased in a local or national nursery. Therefore, the model distinguishes between damaged trees above and below this tree size. There are four different situations related to tree removal and tree size (Table 1). The damaged tree may be either above or below "normal" nursery size, and there may be situations in which the tree needs to be removed or situations in which removal is not necessary.

Table 1. Four situations occur, depending of the size of the damaged tree (above or below "normal" nursery size) and depending on the need to remove the tree. The model applies only if the damaged tree is above "normal" nursery size.

\begin{tabular}{lll}
\hline Size of damaged tree & Tree removal & No tree removal \\
\hline Above "normal" nursery size & 1 & 2 \\
Below "normal" nursery size & 3 & 4 \\
\hline
\end{tabular}

The model applies only if the damaged tree is above "normal" nursery size (situations 1 and 2). In cases for which a new tree of the same species and size may be bought and fully replace the damaged tree, the replacement cost is used (situation 3). If the damaged tree is below "normal" nursery size, and is not removed, the tree value may be assessed as it was before and after the damage. The difference could make up the value of the damage (situation 4). In practice, this situation is not likely to occur. If the tree is above nursery size, but not removed, the tree value will be assessed as it was before and after the damage (situation 2).

The model has four factors (see Table 2 for equations of all factors). The first is the Basis Value (B), which is the price for establishment of a nursery-grown tree of a certain size, similar species, and in the same location, correlated with the difference between the new tree and the damaged tree. The Basis Value is then multiplied with three other factors: Health $(H)$ of the tree, Location $(L)$ of the tree, and Age $(A)$ of the tree. This gives the following simple formula:

$$
\text { Tree value }=B \times H \times L \times A
$$

\section{Basis Value (B)}

The Basis Value is derived as the price for establishing a tree of same species/origin, with a size of 18 to $20 \mathrm{~cm}$ ( 7.2 to 8 in.) circumference at $100 \mathrm{~cm}$ (40 in.) above ground, adjusted with a size factor based on the new and the damaged tree (Table 2). In Denmark, the size of a singlestemmed landscape tree is measured at $100 \mathrm{~cm}$ above ground level and not at the traditional diameter at breast height (dbh). The measurement is suggested to be made in accordance with CTLA (2000) guidelines for measuring circumferences.

Establishment costs should be calculated according to the following checklist, which is inspired by CTLA (2000). Some factors on the list may not be relevant in all situations:

- Removal of the damaged tree, crown, branches, stems, and roots, and deduction of the potential value of wood being sold for other purposes.

- Removal/re-establishment of growing medium-for example, a structural soil (Grabosky and Bassuk 1995; Kristoffersen 1998).

- Price of a new tree as specified above (18 to $20 \mathrm{~cm}$ in circumference $100 \mathrm{~cm}$ above ground), bare rooted unless the species can only be bought balled and burlapped (e.g., beech and oak).

- Planting of the new tree, including possible aeration and watering equipment.

- Re-establishment of surrounding surfaces.

- Maintenance of the tree in a 5-year guarantee period.

- Guarantee of the tree for a 5-year period.

A statement specifying any deviations from the list should follow the calculation. The final price for establishment costs should preferably be an average of the price from two local contractors.

Trees larger than 18 to $20 \mathrm{~cm}$ in circumference are easily available in Denmark. However, that 18 to $20 \mathrm{~cm}$ circumference specification is based on the fact that most new street trees in Denmark are planted at that size (Andersen and Randrup 2001). Further, for most species, the price of the trees changes dramatically from 18 to $20 \mathrm{~cm}$ to the next size, which is often 20 to $25 \mathrm{~cm}$ ( 8 to $10 \mathrm{in}$.). This is due to the production methods: larger sizes often involve several root prunings and liftings in the nursery. Thus, a tree with an 18 to $20 \mathrm{~cm}$ circumference has a favorable relation between size and price. If a tree species is not available at that size, the nearest available size is used for calculating the Basis Value.

The fact that some trees are more difficult (expensive) to produce than others is taken into account in calculating the Basis Value. The price of a nursery-grown tree should be obtained as an average of catalog prices from wellestablished, local nurseries normally dealing with large trees.

The price of a tree of size 18 to $20 \mathrm{~cm}$ in circumference is correlated according to the size of the damaged tree. The size difference is derived as the difference in circumference between the new and the damaged tree $\left(S_{d}-S_{n}\right)$. This difference in size is then multiplied with a price per centimeter of circumference of the new tree $\left(P_{n} / S_{n}\right)$. These two factors relate the price of the new tree to the damaged tree. Also, the species characteristics are taken into account, since the price of the new tree is believed to reflect production 
Table 2. The individual equations used in the VAT03 plant appraisal formula.

Tree value $=B \times H \times L \times A$,

where $B$ is a Basis Value, $H$ is tree health, $L$ is tree location, and $A$ is tree age.

The Basis Value (B) equation is

$B=E+\left(\left(S_{d}-S_{n}\right) \times\left(P_{n} / S_{n}\right)\right)$,

where $E$ is establishment costs, $P_{n}$ is the price of the new tree, $S_{n}$ is the size of the new tree, and $S_{d}$ is the size of the damaged tree.

The Health Factor $(H)$ equation is

$H=r+t+s b+s b t+f / 25$,

where $r=\operatorname{roots}(0-5), t=\operatorname{trunk}(0-5), s b=$ scaffold branches $(0-5)$, sbt $=$ small branches and twigs $(0-5)$, and $f=$ foliage and/or buds $(0-5)$

The Location Factor $(L)$ equation is

$L=n+a+a e+v+e / 12.5$,

where $n=$ natural/ecological adaptation $(0-5), a=\operatorname{architecture}(0-5), a e=\operatorname{aesthetics}(0-5), v=$ visibility $(0-5)$, and $e=$ environmental

factors (0-5)

The Age Factor (A) equation is

$A=$ the square root of $\left(\left(A_{e}-A_{a}\right) \times 2\right) / A_{e}$

where $A_{a}=$ actual age of the tree and $A_{e}=$ expected age of the tree

Table 3. The scheme used for appraising trees with the VAT03 formula.

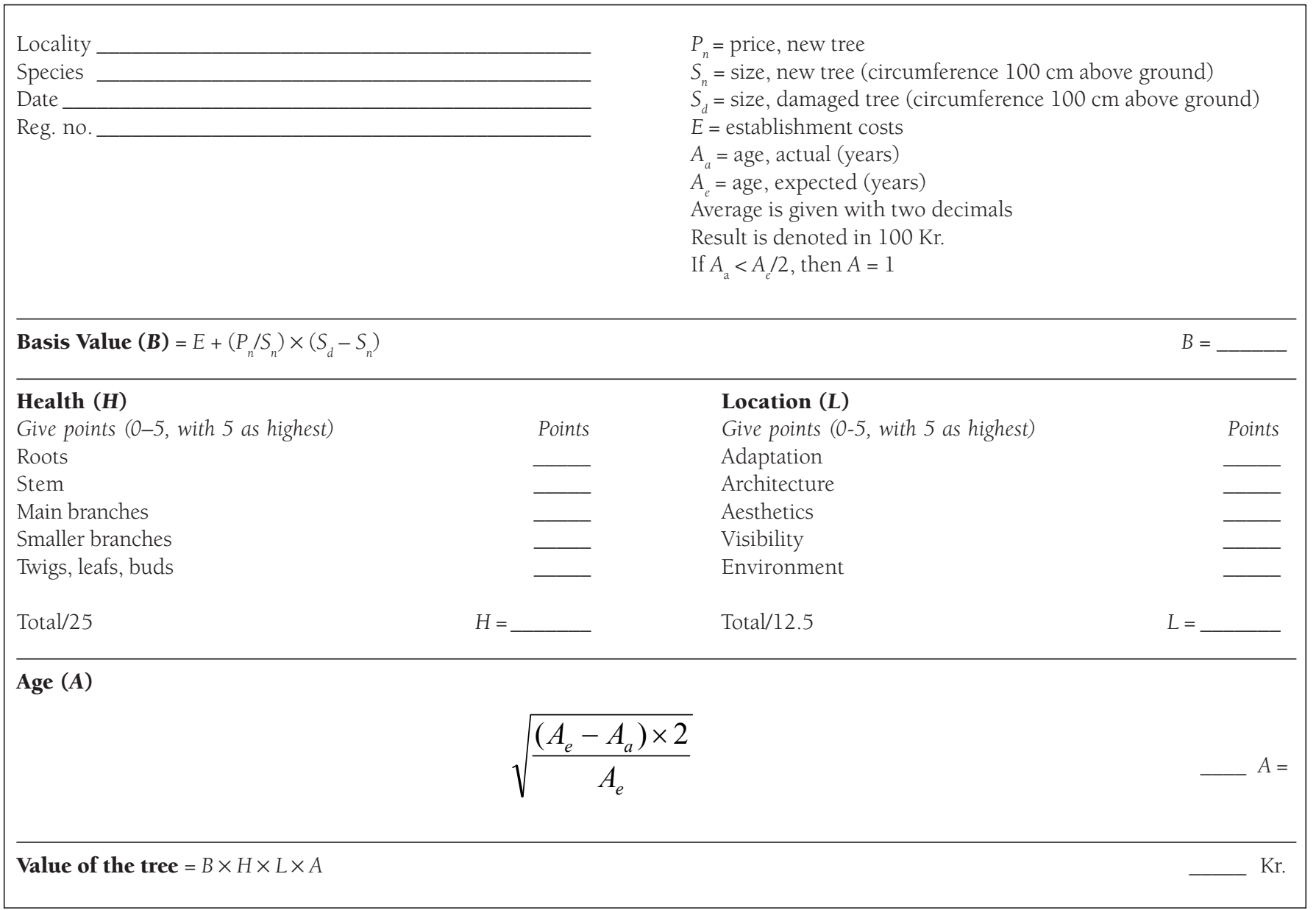


availability (e.g., the fact that a poplar tree in general is easier to produce [cheaper] than an oak tree [more expensive]).

\section{Health Factor $(\boldsymbol{H})$}

It is assumed that a nursery tree is in optimal condition. For this model, this means that an existing tree can never exceed the health status of a newly established nursery-grown tree. At best, the damaged tree that is to be assessed may keep a condition rating of $100 \%$, but most commonly the health factor will be lower than $100 \%$.

The rating of tree health is derived from the CTLA (2000) and Mitchell (1974) systems. It includes a plant rating, determined by the sum of the rating scores of each of five factors: roots, trunk, scaffold branches, small branches and twigs, and foliage and/or buds (Table 2). Each rating uses a scoring system ranging from 0 to 5 , where 5 represents no health problems and/or structural problems. A rating of 5 should be used only after sufficient inspection in the tree. A rating of 0 indicates that the tree is dead or clearly dying. The sum of the five ratings is divided by the maximum amount (25), which gives a value of $H$ between 0 and 1.00 .

The CTLA (2000) formula uses a rating at each of the five factors, from 1 to 4 . We chose to use a broader scale, to further minimize the effects of each individual rating. Similar to CTLA (2000), a checklist for each of the five factors follows the model.

The rating should be based on the actual condition of the tree, apart from the damage that led to the assessment. Thus, the rating is not a reflection of general or genetic behaviors of the species, but a clear reflection of the health of the actual tree.

\section{Location Factor (L)}

The location of a tree may raise or lower its value. Location may accentuate the positive characteristics or limit the negative in relation to natural/ecological adaptation, architecture, aesthetics, visibility, and environmental factors. In principle, it does not matter whether the damaged tree is self sown or planted.

As in the case for the Health Factor, a rating scale from 0 to 5 is used for each of five factors, with a maximum sum of 25. The sum is divided by 12.5 to make it possible for the Location Factor to act positively on the overall rating (giving a factor of 0 to 2.00) and to minimize the effect of each individual rating (Table 2). Half points may be used for each of the five ratings. A rating of 2.5 may be used if the rating is neutral, which means that the tree does not contribute either positively or negatively to its location.

The general values of a species are not assessed. For example, it is not important that the species has beautiful flowers. But if the assessed tree has flowers that contribute to the quality of the tree in the specific location, that should be acknowledged in the assessment of the Location Factor.
Therefore, species does indirectly influence the Location Factor.

The natural/ecological adaptation rating is an assessment of the tree's vulnerability to de-icing salts, air pollution, or similar unavoidable abiotic stress factors. The better the tree can adapt to the specific stress factors on the specific location, the better the rating that should be given. An old, historically and/or culturally important tree will be valued high. The general level of adaptation should be assessed in relation to the specific local climatic and soil conditions.

The tree should be assessed in relation to the architectural context, in which it could contribute either in a positive or a negative way. There may be locations in which a tree negatively counteracts and influences the overall architectural context. In such situations, the rating of the architectural context should be negative. However, in many cases, the positive influence of the tree is high (e.g., in a systematic planting where each individual tree plays an important role). The tree as a guide for traffic (e.g., as an orientation mark) (Lynch 1988) is important for this specific rating.

The tree should be assessed in relation to its aesthetic features. These may be flowers, bark, fruits, foliage, and other features, in relation to the specific location of the tree. The more attractive the features, the higher the rating.

The visibility factor is related to the number of people who potentially enjoy the tree. In principle, a tree gains a high visibility rating if there are many people in the area. A tree with a high visibility rating typically is located in an urban setting.

The environmental factor is related to the climatic and environmental consequences that the damaged tree has on its specific location. These consequences may be in providing shade or light, and protection against wind, dust, and other factors. Under Danish conditions, only a few species are rated as problematic according to the Danish Asthma and Allergy Association (DAAA 2004): hazel (Corylus spp.), elm (Ulmus spp.), alder (Alnus spp.), and birch trees (Betula spp.).

\section{Age Factor (A)}

Based on growth, the Basis Value of a tree will increase through its entire lifetime. The Health and Location Factors will influence this value; however, the result will often be that the tree will gain a relatively high value even in its old age. In the Danish model, a high age of the tree will influence the overall value of the tree in a negative way.

Koch, who introduced an age factor in a German tree appraisal model (Koch 1987), acknowledges the presence of this factor. The Age Factor is effective when the tree has exceeded half of its life expectancy. As the tree nears its total expected lifetime, the Age Factor will lower its overall value substantially (see Figure 1). In addition to low Health Factor scores, the Age Factor ensures that trees with serious health problems will be reduced in value due to a decreased life expectancy. 
However, there may be old and decaying trees that should be acknowledged for their ecological and/or cultural values. Such trees will usually be valued high in the Location Factor in relation to the natural/ecological adaptation, since they have survived on the specific location for a very long time and have shown suitability for the specific growing conditions. Also, a tree that may be considered to have a low Health status in general terms may be considered high in ecological terms. Such trees may be located in an area where safety is not the main issue, and a longer life expectancy may be considered. Thus, there will be a smaller reduction due to the Age Factor in comparison to a tree that has no significant ecological value.

To estimate the Age Factor, the actual as well as the expected total age of the tree is needed. Several methods may be used to estimate the actual age of the tree. In cases for which the tree is to be removed, the growth rings of the tree may be counted. In other cases, documentation of when the tree was planted can be assessed. However, in most cases, the age of the tree must be assessed as a professional estimate, which requires experience and knowledge of tree growth related to the local area. Mitchell (1974) has provided a helpful guideline to estimate a tree's age using a nondestructive method.

The expected age may be difficult to assess unless the tree is very close to the end of its total expected lifespan. Therefore, a list of the most common species and their life expectancies under urban conditions has been developed. The list is based on a similar list made by Pribbernow and Fritzon (1980). However, it is important to make individual judgments for each tree and use the list as a guideline only. In many cases, it is primarily a question of judging whether the tree has lived more than half of its total expected life. If not, there is no reduction based on the Age Factor. In the assessment of the Age Factor, it should be evaluated whether the tree is hazardous, and, if so, it should probably be felled.

The Age Factor is derived mathematically based on the relationship between the estimated remaining number of years the tree would have lived had it not been damaged, and half of the life expectancy of the tree. To estimate the decrease in value as the tree gets older, the square root of this relationship is used (Table 2). Hypothetically, this relationship ensures that the tree will get a value of 0 if the tree is already dead, and that the expected total lifespan equals the actual age of the tree.

In Figure 1, the actual effect of the Age Factor is shown.

\section{Examples}

A formula has been developed to facilitate the use of the model (Table 3). Three cases from the city of Copenhagen are described to illustrate the use and effectiveness of the model on different trees with different health statuses, total life expectancies, and different locations.

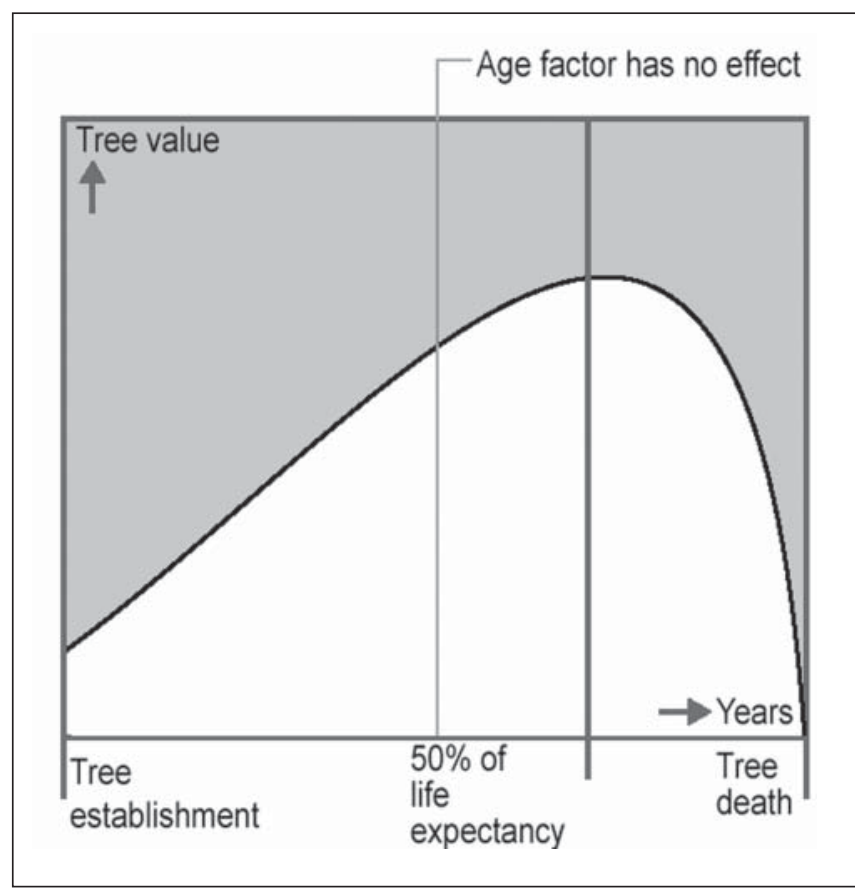

Figure 1. Age Factor influence on VAT03. From Randrup et al. (2003). The Age Factor has an influence on the total tree value when the tree has reached half of its expected total lifespan. However, it does not have a major impact until the tree approaches senescence.

Tree 1: Tilia cordata (Figure 2). The tree is estimated by the city planners to be 47 years old, and it has a stem circumference of $147 \mathrm{~cm}$ (58.8 in.). The establishment costs for a new tree on this location are rather high (approximately US $\$ 3,300$ ) because it is in a paved area, and because it is assumed that a new tree will be planted using structural soils.

The tree is assessed as healthy, with an overall Health Factor of 0.82. The tree is located on a small square in the center of Frederiksberg, one of the most populated and busiest areas of the city. The square functions as a focal point for traffic from three different directions, and it shades a bus stop and a small local hot dog dealer. The Location Factor is high (1.56).

It is assumed that the tree may live up to 120 years in this location. Thus, the tree has not yet reached half of its life expectancy, and no deduction is made for the Age Factor.

The total value of this tree is US\$7,600.

Tree 2: Aesculus hippocastanum (Figure 3). The tree is estimated to be approximately 75 years old, and it has a stem circumference of $240 \mathrm{~cm}$ (96 in.). The establishment costs for a new tree on this location are similar to tree 1 (approximately US $\$ 3,300$ ) because it is in a paved area, and it is assumed that a new tree will be planted using structural soils. 
The tree is assessed as healthy, with an overall Health Factor of 0.80 . The tree is located on a moderately busy street just outside the city center. The tree fits in very well with the surrounding architecture and a wall between nearby buildings, and the street has been built with consideration for the tree. Thus, the Location Factor is high (1.52).

It is assumed that the tree may live up to 100 years in this location. Therefore, the Age Factor has a rather large influence on the overall value of this tree (0.71).

The total value of this tree is US\$8,900.

Tree 3: Sorbus intermedia (Figure 4). The tree is estimated to be approximately 100 years old, and it has a stem circumference of $175 \mathrm{~cm}$ (70 in.). The establishment costs for a new tree on this location are estimated to be low (approximately US $\$ 1,000$ ), due to an existing large planting area.

The tree is assessed as unhealthy with the trunk, scaffold branches, and smaller branches showing clear indications of decay. The tree has been severely pruned for many years, and it is now evident that it will not have many more years to live (estimated 10 years). The Health Factor of the tree is 0.60 .

The tree is located on a residential street with limited traffic. Aesthetically, it is questionable whether the tree contributes in a positive way because it once was one of several trees on a row, but now it is one of very few old and intensively pruned trees, giving the street a poor impression. The Location Factor is estimated to be 1.20.

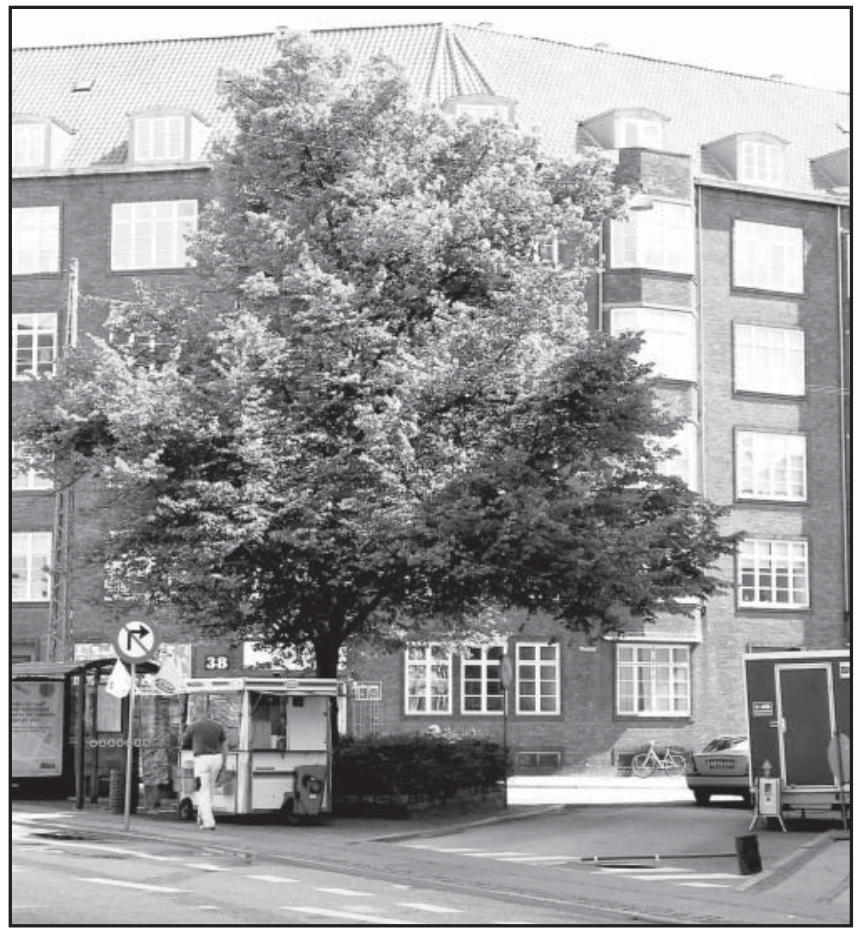

Figure 2. Tilia cordata located in central Copenhagen. Value according to VAT03 is US\$7,600 (photo credit: Lars E.A. Poulsen).
Based on the estimate that the tree has only 10 years left, the Age Factor has a very high influence on the overall value of this tree (0.43).

The total value of this tree is US\$1,100, which is only a little more than the establishment costs of a new tree (US\$850).

\section{Value in Comparison to CTLA}

The VAT03 model has been clearly derived from the CTLA (2000) approach. However, it has not been possible to establish plant appraisal committees, even though in Denmark, one committee would probably be able to cover the entire country. Most of the tasks being put on such a committee have been incorporated into the Danish model. These include no use of species rating, use of actual costs of plant purchase and installation, and no use of unit tree costs. The most influential factor in the model is the Basis Value, and thus the establishment cost. If this factor is based on a minimum of two independent calculations from professionals, the variation among assessments will be limited.

In Table 4, two central factors used in the CTLA method (2000) are incorporated into the new Danish model in order to show the differences in total value using different factors.

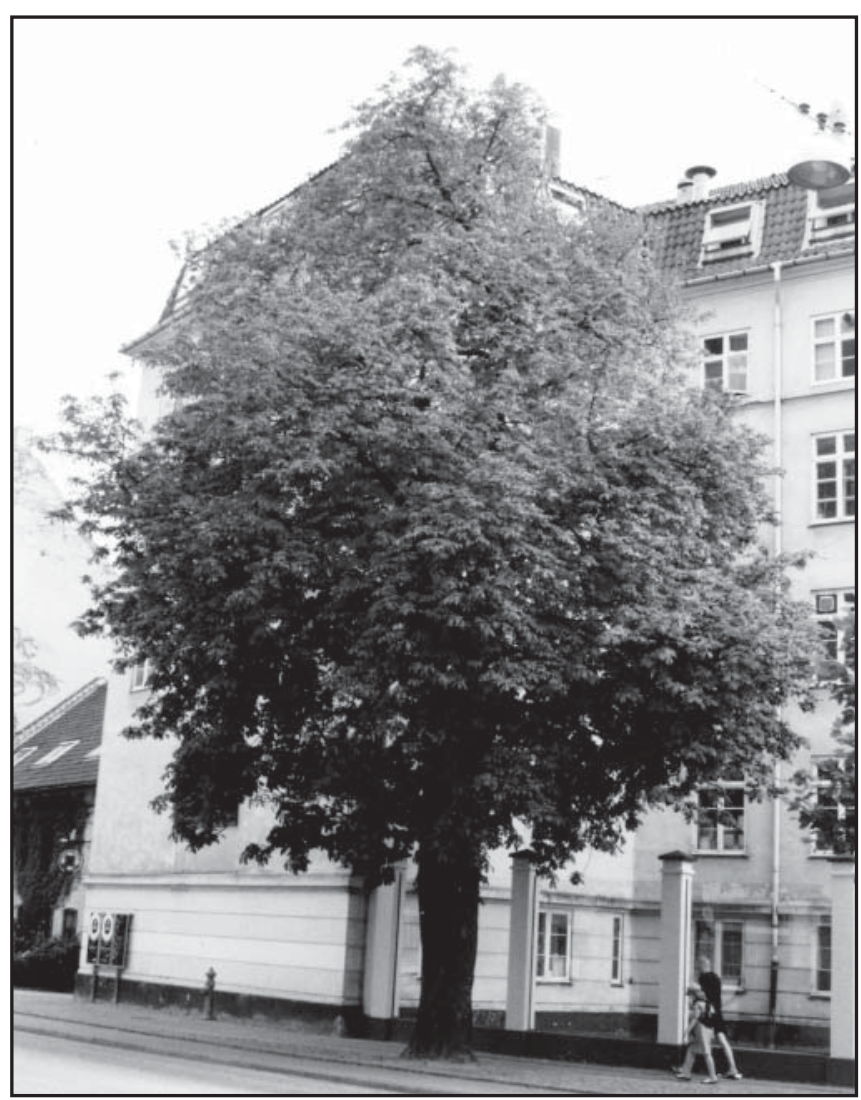

Figure 3. Aesculus hippocastanum located just outside central Copenhagen. Value according to VAT03 is US\$8,900 (photo credit: Lars E.A. Poulsen). 


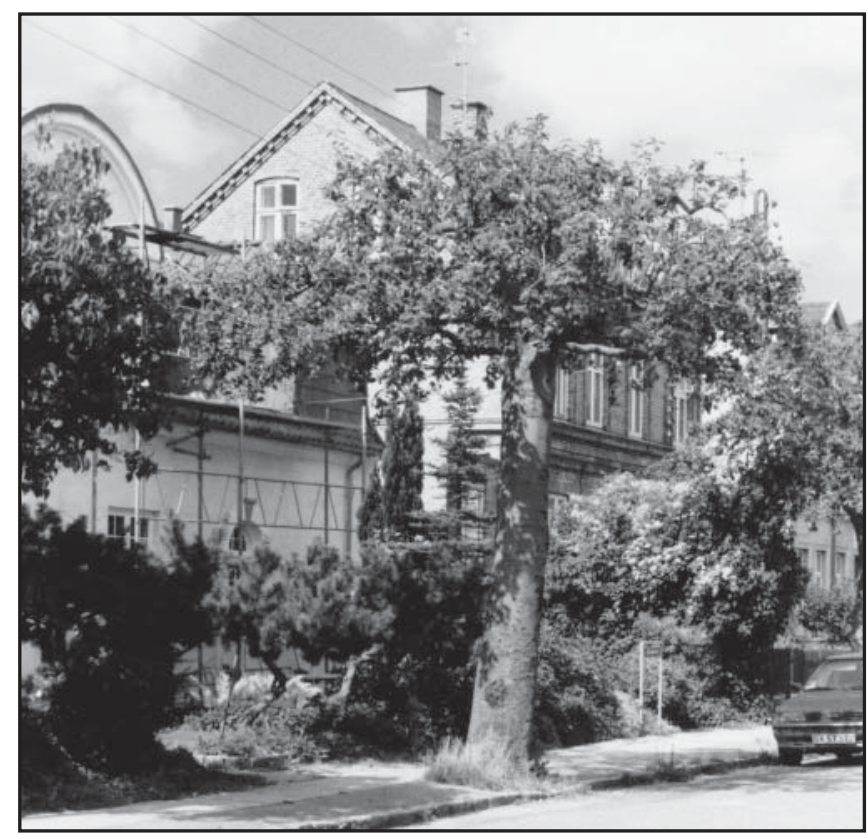

Figure 4. Sorbus intermedia located just outside central Copenhagen. Value according to VAT03 is US\$1,100 (photo credit: Lars E.A. Poulsen).

The value of three individual trees would increase 1.9 to 3.6 times using trunk area instead of circumference, and 4.2 to 9.3 times if the largest available tree was used instead of a fixed size of 18 to 20 (7.2 to $8 \mathrm{in}$.) cm circumference at 100 $\mathrm{cm}$ (40 in.) above ground. The prices shown for large trees in Table 4 could be even higher if trees were imported from Germany or The Netherlands.

In the VAT03 model, the species rating system in the CTLA method (2000) is not used. Instead, the tree species is evaluated indirectly by the Condition and Location factors. Also, the tree species is reflected in the nursery price, because certain trees are easier to produce than others. If a tree unexpectedly is doing well in a certain area, that will then be regarded as an asset.

Table 4. Tree value (US\$) by use of VAT03. The values are related to the effects in price if trunk area and largest available trees (CTLA 2000) were used. The value of these three individual trees would increase 1.9 to 3.6 times using trunk area instead of circumference, and 4.2 to 9.3 times if the largest available tree was used instead of a fixed size of $1820 \mathrm{~cm}(7.2$ to $8 \mathrm{in}$.) circumference at $100 \mathrm{~cm}$ (40 in.) above ground.

\begin{tabular}{llllll}
\hline Species & VAT03 & $\begin{array}{l}\text { (Adjusted) } \\
\text { trunk area }\end{array}$ & $\begin{array}{l}\text { Difference } \\
\text { (times) }\end{array}$ & $\begin{array}{l}\text { Largest } \\
\text { available } \\
\text { tree* }\end{array}$ & $\begin{array}{l}\text { Difference } \\
\text { (times) }\end{array}$ \\
\hline Tilia cordata & 7,600 & 27,300 & 3.6 & 31,700 & 4.2 \\
Aesculus hippocastanum & 8,900 & 31,600 & 3.6 & 83,000 & 9.3 \\
Sorbus intermedia & 1,100 & 2,200 & 1.9 & 8,800 & 7.7 \\
\hline
\end{tabular}

*Circumference is measured $100 \mathrm{~cm}$ above ground level, in accordance to Danish nursery practice.

\section{Watson (2002) showed that CTLA Trunk Formula} method derived lower values than four other international valuation models. Watson concluded that all the tested methods were widely adapted in each country of origin. The reason for some methods yielding high values and others giving low values was not evident. Under Danish conditions, the values derived by the use of this new model should be regarded as high (valuations are approximately ten times higher under the new model). However, the model may not be creating a price high enough to discourage builders, entrepreneurs, and others from felling trees. In such cases, the felling act may be regarded as a felony, and it will be up to the court to decide a penalty. The assessed value of the tree may be used as a basis for setting a fine.

In Table 5, the value of three trees were assessed using both VAT03 and the CTLA (2000) Trunk Formula methods. While this is not a statistical test of the two models, the difference among the three trees indicates some of the major differences between the two models.

The Tilia and the Aesculus are both mature trees, located in prestigious settings, and judged to be in good condition. Both species were given the same species rating (0.80). The fact that the Aesculus is larger than the Tilia gives it a value more than three times higher than the Tilia. Both trees were valued lower under the VAT03 model than under the CTLA (2000) model. The Tilia does not have a reduction in value due to age, but the Aesculus has a $29 \%$ reduction because it is assumed that the tree has only 25 years left to live.

However, the difference in tree size does not make a major impact on the overall VAT03 values. The two trees are assessed to have an almost equal value, despite the difference in ages.

The Sorbus is valued very low using the VAT03 model, primarily due to its advanced age and its poor condition rating. The CTLA (2000) Trunk Formula method also values this tree relatively low, but, presumably because of its size, this tree is still valued higher than the younger, healthier, and better-located Tilia. This is not the case using the VAT03, where an old and structurally unsound tree always will be valued low. Actually, this tree will generate a value that is only slightly higher than the costs of a new tree.

CTLA (2000) describes a variation of different tree appraisal approaches. Therefore, it is possible that a CTLA appraisal of the Sorbus should be done using another method than the Trunk Formula used in the example, (e.g., Cost of Cure). Using such a method could result in a negative value due to the hazardous nature of the tree. 
Table 5. Differences in values (US\$) of three trees based on VAT03 and CTLA (2000) Trunk Formula method, respectively.

\begin{tabular}{llllllll}
\hline Species & $\begin{array}{l}\text { Diameter } \\
(\mathrm{cm})\end{array}$ & Health & Location & $\begin{array}{l}\text { Actual } \\
\text { age }\end{array}$ & $\begin{array}{l}\text { Expected } \\
\text { age }\end{array}$ & VAT03 (US\$) & CTLA 2000 (US\$) \\
\hline Tilia cordata & 43.9 & 0.89 & 0.85 & 47 & 120 & 7,600 & 12,000 \\
Aesculus hippocastanum & 76.4 & 0.88 & 0.83 & 75 & 100 & 8,900 & 37,000 \\
Sorbus intermedia & 55.7 & 0.63 & 0.52 & 100 & 110 & 1,100 & 13,900 \\
\hline
\end{tabular}

\section{DISCUSSION}

\section{Implementation in Denmark}

It is evident that in developing a new model, one can make the value of a tree be almost as high as wanted. With the VAT03 model, the goal was to create a model that could be used by the entire green industry in Denmark. Also, since previous court cases compensated for a full-grown and healthy tree at no more than 5.000 Danish Kr. (approximately US\$800), there was practically no guide to what values the new model should generate (Holgersen 1995). The primary argument for setting the value of the trees then became what was sought to be realistically accepted by the Danish court system.

The following Danish associations have positively acknowledged the VAT03 model: The Danish Tree Care Organization (ISA's Denmark Chapter), The Danish Council of Landscape Constructors, The Association of Danish Landscape Architects, Practicing Landscape Architects of Denmark, City and Municipal Park Directors Association, The Danish Horticultural Society, and The Danish Garden and Landscape Council. This broad acceptance has given the model certain reliability within the Danish court system from its very introduction.

The model has now been used in several, and very different, court cases (e.g., Helsingør Civil Court BS 1-429/ 2003 [multiple trees in a woodland setting] and Frederikssund Civil Court BS 1-2112/2002 [single tree on residential property]), and the model has proved to be trustworthy in the sense that it has been accepted as an argument for economic compensation.

The Age Factor is a factor that we felt was necessary to include for several reasons, not the least of which was the fact that we wanted the Danish court system to respect the formula. The Age Factor is similar to traditional insurance thinking, in which an item is reduced in price due to its age. However, for a tree, there is no direct relationship between age and loss in value. Therefore, the Age Factor is supplemented by the Health Factor. If the tree is old and healthy, it may also be justified that it has many years left to live, which will reduce the effects of the Age Factor. In other words, an old tree may not be affected dramatically only because it is old but because it is weak and has few years left to live.

The model is likely to be implemented in the other Nordic countries, where the legal and cultural environments are similar to the Danish. The model should not be used for trees with a special national or historical status or for trees judged by the public as invaluable.

The VAT03 model is by no means a perfect model, but it has proven its worth under Danish conditions. There might be some indications that the values derived by the use of VAT03 are too low. Therefore, the money derived from selling the model is placed in a fund, which will be used entirely to update and improve the model. While it may no longer be possible to drastically change the level of the assessed value of a tree, it will be possible to alter one or several factors in order to increase the value, if so needed.

\section{LITERATURE CITED}

Andersen, F, and T.B. Randrup. 2001. Skab variation i byens træer med flere arter [Create Variation among Urban Trees by Use of Multiple Species]. Videnblade Park- og Landskab, nr. 4.6-25. Forskningscentret for Skov \& Landskab. 2 pp. [In Danish].

Council of Tree and Landscape Appraisers (CTLA). 1992. Guide for Plant Appraisal (8th ed.). International Society of Arboriculture, Champaign, IL.

- 2000. Guide for Plant Appraisal (9th ed.). International Society of Arboriculture, Champaign, IL.

Danish Asthma and Allergy Association (DAAA). 2004. www.astma-allergi.dk. (accessed 6/04).

Forrest, M., C.C. Konijnendijk, and T.B. Randrup (Eds.). 1999. COST E12, Research and Development in Urban Forestry in Europe. European Commission, EUR 19108. Luxembourg. 363 pp.

Grabosky, J., and N.L. Bassuk. 1995. A new urban tree soil to safely increase rooting volumes under sidewalks. J. Arboric. 21:187-201.

Hageselskapet. 1998. Taksering av grøntanlegg [Valuation of Green Areas]. Det Norske Hageselskap, Avd. Fag, Oslo, Norway. [In Norwegian].

Harris, R.W., J.R. Clark, and N.P. Matheny. 2004. Arboriculture: Integrated Management of Landscape Trees, Shrubs, and Vines (4th ed.). Prentice Hall, Englewood Cliffs, NJ.

Helliwell, D.R. 2000. Amenity Valuation of Trees and Woodlands. Guidance Notes. Arboricultural Association, Hampshire, UK. 
Holgersen, S. 1995. Skader og erstatning i det grønne miljø [Damage and compensation in the green environment]. Grønt Miljø; 3:20-21. [In Danish].

Koch, W.1987. Aktualisierete Gehölzwerttabellen—Bäume und Sträucher als Grundstücksbestandteile an Straßen, in Parks und Gärten sowie in der freien Landschaft. Einschließlich Obstgehölze. 2. völlig überarbeitete und erweiterte Auflage. Verlag Versicherungswirtschaft, Karlsruhe, $251 \mathrm{~S}$.

Kristoffersen P. 1998. Designing urban pavement sub-bases to support trees. J. Arboric. 24:121-126.

Lynch, K. 1988. The Image of the City. MIT Press, Cambridge, MA; and London, UK.

Miller, R.W. 1997. Urban Forestry: Planning and Managing Urban Green Spaces (2nd ed.). Prentice Hall, Englewood Cliffs, NJ.

Mitchell, A.C. 1974. A Field Guide to the Trees of Britain and Northern Europe. William Collins Sons, London, UK.

Pauleit, S., N. Jones, G. Garcia-Martin, J. L. GarciaValdecantos, L.M. Rivière, L. Vidal-Beaudet, M. Bodson, and T.B. Randrup. 2002. Tree Establishment Practice in Towns and Cities-Results from a European Survey. Urban For. Urban Green. 1(2):83-96.

Poulsen, L.E.A. 1999. Værdisætning af træer-oplæg til en ny værdisætningsmodel for træer i Danmark. [Valuation of Trees-Proposal for a New Danish Appraisal Model. Bachelor's thesis. Royal Veterinary and Agricultural University, Denmark. [In Danish].

Pribbernow, H., and P. Fritzon. 1980. Värdering av träd och buskar [Assessing trees and shrubs]. Stockholms Fritidsforvaltning. Parkenheten, Tabell 1. [In Swedish].
Price, C. 2003. Quantifying the aesthetic benefits of urban forestry. Urban For. Urban Green. 1(3):123-134.

Randrup, T.B., L. Poulsen, and S. Holgersen. 2003. VAT 03Værdisætning af Træer [Valuation of Trees]. Forlaget Grønt Miljø, Copenhagen. 32 pp. [In Danish].

Thompson, R., R. Hanna, J. Noel, and D. Piirto. 1999. Valuation of tree aesthetics on small urban-interface properties. J. Arboric. 25(5):225-234.

Thyer, P. 1996. The Thyer Tree Valuation Method. www.intercoast.com.au/ thyer-p (accessed 6/04).

Tolstrup, E. 1972. Vurdering af prydtræer [Valuation of Ornamental Trees]. Landskab, Arkitektens Forlag, Copenhagen. [In Danish].

Tyrväinen, L., H. Silvennoinen, and O. Kolehmainen. 2002. Ecological and aesthetic values in urban forest management. Urban For. Urban Green. 1(3):135-150.

Watson, G. 2002. Comparing formula methods of tree appraisal. J. Arboric. 28(1):11-18.

Acknowledgments. Landscape architect Lars E.A. Poulsen and editor Søren Holgersen have played an invaluable role in the development of the new Danish model. Also, two anonymous reviewers are acknowledged and thanked for their valuable and constructive comments.

Professor

Forest and Landscape Denmark

Royal Veterinary and Agricultural University, Copenhagen

Rolighedsvej 23, 2

1958 Frederiksberg C

Denmark 
Résumé. Inspiré par le Conseil américain des évaluateurs en arbres et en aménagements paysagers, l'Association danoise en entretien des arbres (chapitre du Danemark de l'ISA) a créé un groupe national d'experts, représentants diverses associations de l'industrie des espaces verts, dans le but de développer un modèle commun d'évaluation des arbres qui tient compte des spécifications du climat, de la culture et des traditions danoises. Le modèle (VAT03) comporte quatre facteurs primaires que sont: 1) une valeur de base, 2) la condition de santé de l'arbre, 3) la localisation de l'arbre, et 4) l'âge de l'arbre. Le nouveau modèle établit une valeur qui est approximativement 10 fois plus élevée que celle produite dans le passé par la pratique. Quoiqu'il en soit, les valeurs d'arbres utilisées dans ce modèle sont présumées être plus basses que celles qui peuvent être calculées par d'autres modèles. Le modèle a été introduit en 2003 et a déjà été utilisé dans plusieurs causes de natures très variables en cour.

Zusammenfassung. Inspiriert durch den Rat der Amerikanischen Baum- und Landschaftsgutachter initiierte die dänische Baumpflegevereinigung (ISA Denmark Chapter) eine Gruppe von nationalen Experten, die die verschiedenen Vereinigungen der Grünen Industrie repräsentieren, um ein allgemeines Baumbewertungsmodell mit besonderer Relevanz für das dänische Klima, die Kultur und Tradition zu entwickeln. Das
Modell (VAT03) hat 4 Hauptfaktoren: 1. einen Basiswert, 2. Gesundheitszustand der Bäume, 3. den Standort und 4. das Baumalter. Das neue Modell etabliert einen Wert, der schätzungsweise 10mal so hoch ist wie in der Vergangenheit. Dennoch sind die Baumwerte unter Anwendung von diesem Modell niedriger als in den anderen Modellen. Das Modell wurde 2003 eingeführt und wurde bereits in vielen unterschiedlichen Gerichtsfällen verwendet.

Resumen. Inspirado por el American Council of Tree and Landscape Appraisers, la Asociación Danesa de Cuidado de los Árboles, (Capítulo danés de la ISA) conformó un grupo de expertos nacionales, representando varias asociaciones de la industria verde, con el fin de desarrollar un modelo común de evaluación de árboles de relevancia específica para el clima, la cultura y las tradiciones danesas. El modelo (VAT03) tiene cuatro factores primarios: 1) un valor base, 2) condiciones de salud del árbol, 3) localización del árbol, y 4) edad del árbol. El nuevo modelo establece un valor que es aproximadamente 10 veces más alto de lo que fue en la práctica pasada. Sin embargo, los valores usando este modelo fueron presumiblemente más bajos que los que fueron obtenidos por otros modelos. El modelo fue introducido en 2003 y hasta el momento ha sido usado en varios y muy diferentes casos en la corte. 